\title{
Control-Oriented Inventory Production and Sales Activities in Chinese Manufacturing Firms
}

\author{
Haihong $\mathrm{He}^{1}$ \\ ${ }^{1}$ College of Business and Economics, California State University, Los Angeles, Los Angeles, USA \\ Correspondence: Haihong He, Accounting Department, College of Business and Economics, California State \\ University, Los Angeles, 5151 State University Drive, Los Angeles, CA 90032, USA
}

Received: January 30, 2018

Accepted: February 25, 2018

Online Published: March 8, 2018

doi:10.5430/afr.v7n2p134

URL: https://doi.org/10.5430/afr.v7n2p134

\begin{abstract}
This study uses a sample of Chinese manufacturing firms to examine the association between current period inventory production costs and sales changes in adjacent past and future periods. The results find an overall significant association between inventory production and the past period sales changes, but no association between inventory production and the future period sales changes. Further, we find that in firms with high return on assets, inventory production is only associated with the past period sales changes, but not with the future period sales changes; in contrast, in firms with low return on assets, inventory production is only associated with the future period sales changes, but not with the past period sales changes. The results, on one hand confirm our perception of control oriented management accounting practices in China, on the other hand suggest that firm performance is associated with such management emphasis in China.
\end{abstract}

Keywords: inventory management, decision making, management control, Chinese manufacturing firms, firm performance

\section{Introduction}

This study investigates the association between Chinese manufacturing firms' inventory production and past/future period sales changes. We perceive the existence of an association between the current period inventory production and the past period sales changes as an indication of "control" oriented management accounting practices since past information is generally preferred in management control. In contrast, we perceive the existence of an association between the current period inventory production and the future period sales changes as an indication of "decision-making" oriented management accounting practices since firms should base their production decisions on the future projected information.

The modern management accounting practices are developed in firms in developed Western countries to maximize firm value by providing useful information for managers engaged in various tasks. Management accounting has two major roles - decision-making and management control (Zimmerman 2013). Decision-making management uses relevant future information while control management prefers verifiable past information to monitor managers' performance. Inventory production (supply) should be determined to respond to inventory sales (demand) in current and adjacent periods. A good inventory decision should reduce the costs associated with inventory overage and shortage. Thus, in management accounting practices, production budget is prepared based on projected sales in the budgeting period and adjustment for the beginning and ending inventory levels which reflects the prior and future period sales activities. Similarly, empirical accounting research (Roychowdhury 2006) expresses inventory production as a function of current period sales and past period sales.

We use cost of goods sold adjusted for inventory change to proxy for inventory production and study the association between inventory production and past/future sales in Chinese manufacturing firms to gauge whether firms make a trade-off between the two roles - decision-making and management control. China has been a centrally controlled economy with many state-owned enterprises. During the recent decades of economic reform, many state-owned enterprises become privatized, a great number of private corporations emerge and foreign capital investments permeate in most industries in the whole country. However, corporate culture in China is still strongly influenced by the central planning and control.

Using a sample of Chinese manufacturing firms in the period of 2005-2013, we find that production costs in 
manufacturing firms are related to the past period sales growth, but not related to the future period sales growth. We attribute our findings to Chinese firms' greater emphasis on the past information instead of the future-oriented information in scheduling inventory production. Given that effective inventory production and management generally should be responsive to anticipated sales needs in the future (not the past sales which is often deemed as irrelevant in decision-making), our findings are consistent with the perception of poor management practices in China (Bloom and Van Reenen 2010). Additionally, we partition the sample based on return on assets (ROA). In firms with high ROA, production costs are related to the past period sales changes and not related to the future period sales changes; while in firms with low ROA, production costs are related to the future period sales changes and not related to the past period sales changes. The results that better performing Chinese manufacturing firms use the past period sales information suggest that, contrary to the generally perceived good management accounting practices in scheduling production, i.e., production should anticipate and respond to future sales changes, Chinese firms might choose different management accounting practices to optimize business operations and improve operational results.

Management accounting practices in Chinese firms have been extensively researched (Dua et al. 2008). Most research (47\%) focuses on the control functions and only $2.5 \%$ examines the decision-making functions (Dua et al. 2008). Apart from the possible explanation that researchers are more likely to conduct research in areas to which they have easy access to, the research interest also reflects the business strategy priority in management accounting practices, i.e., managers in China are probably more concerned with control than decision-making in managing businesses. Our findings that Chinese manufacturing firms rely on the past period sales instead of the future period sales in the production corroborate that the need for control with emphasis on past information outweighs the need for decision-making in these firms.

Our research uses a large sample data to add evidence to the current knowledge of not only management and management accounting practices but also the cultural effect on the choice of management accounting practices in China. China has the most chronologically intact culture in the world and the cultural differences affect managers' behaviors in China that are different from Western countries (Chow et al. 2000). China is also the most dynamic and rapidly changing economy of the last few decades. Although China has not yet offered new management innovations, it certainly provides more management lessons today than do most other countries (Hout and Michael 2014). Using a large sample of Chinese manufacturing firms that navigated through the past decades of unique and turbulent business environments, our research contributes to the extant research on how Chinese manufacturing firms manage inventory.

Our research also offers new insights into the role of decision-making and management control not only in China, a country with deeply rooted local culture and influx of Western management practices, but also for the rest of the world. In today's ever changing business environments, managers should be agile, responsive and improvisational. Chinese firms' lessons and their weighing on decision-making and management control allows us to rethink different business strategies compatible with different firms in different business environments and the divergence in applying management accounting practices.

\section{Literature Review and Research Questions}

\subsection{Inventory Management, Management Control and Decision-Making}

Inventory production decisions should be made to avoid either overproduction or shortage of inventory. A mismatch between inventory production and inventory sales will cost firms and adversely affect profits and value. Rumyanstev and Netessine (2007) find that superior earnings are associated with responsiveness in inventory management; specifically, both current and forward return on assets are negatively associated with faster inventory growth or faster inventory decline relative to sales.

Overproduction and shortage can be avoided when lean production is implemented to meet current sales needs, and firms are able to quickly adjust production or inventory levels for anticipated future sales change. This requires the effective use of budgeting, the advantages of which include planning resources, communication of information, and bottleneck identification. When an effective budgeting system is established and runs smoothly, production can be expected to be scheduled based on the expected sales adjusted for any future inventory changes, which is a function of future sales. Thus, in management accounting practices, the production budget is prepared based on projected current period sales and projected future period sales. In addition, a production budget should also consider the existing inventory from prior period activities. This relationship has been extensively used in empirical accounting research such as Roychowdhury (2006) to expresses inventory production as a function of current period sales and prior period sales. 
According to Zimmerman (2013), management accounting practices serve two purposes - decision management and management control, and often require a trade-off between the two. Decision management emphasizes information precision and planning, whereas control intends to reduce agency conflict and prefers verifiable past information. Many management accounting choices, including inventory production, in particular, are a reflection of such consideration and balance. For example, the need for control is greater when there is a greater concern that lower level managers might provide biased estimation; thus, inventory budgeting is more likely to adopt a top-down approach rather than bottom-up with less reliance on the managers' participation and more use of past year information as the base number in planning. On the other hand, when the goal is to make better decision management, budgeting is more likely to adopt a bottom-up approach and to incorporate future information provided by the lower level managers, who often possess special business knowledge for better projection. In summary, the use of future information is more relevant for decision-making but is less verifiable, and the use of past information is less relevant in decision-making but more verifiable.

A few prior studies examine the interplay of management control and decision-making in different contexts using non-empirical methodology. For example, Chen et al. (2015) use an experiment to show the interplay of control and decision-making in management accounting practices. Chen et al. (2015) show that preparing disaggregated (compared to aggregated) forecasts leads to greater improvements in forecast accuracy and less bias in the absence of performance-based incentives than in the presence of performance-based incentives. They suggests that a control system design choice affects decision-making quality. Another study, Baiman et al. (2010) models the optimal-sized inventory buffer as a function of a principal's desired level of effort, showing that principal-agent problems affect decision-making, with a negative association between the inventory buffer size and worker motivation. Specifically, Baiman et al. (2010) show that when an agency problem is sizable (i.e., for small obedient effort from agents or less worker motivation), the principal prefers larger buffers in inventory; however, when an agency problem is small (i.e., for larger levels of obedient effort from agents or greater worker motivation), smaller buffers were deemed optimal. Both research suggest that emphasis on control function could negatively affect the decision making quality.

Prior empirical research mostly focuses on why firms make decisions to overproduce. Most studies attempt to explain overproduction from financial reporting earnings management incentives (e.g., Roychowdhury 2006; Cook et al. 2012). Very limited number of studies, for example, Bruggen et al. (2011) use managers performance measures to explain from management accounting perspective why firms make the decision to overproduce in excess of sales demand in an auto manufacturer. Overall, the prior research has shown some non-empirical evidence that the interplay of decision-making and management control drives management actions in inventory production. However, there are very few empirical evidence on this topic.

We choose to investigate decision making and management control in China because we suspect that the tension between the two roles might exist in business practices as China is culturally and politically influenced by collectivism and centralized control (Harrison and McKinnon 1999) that decision making might acquiesce to management control. Secondly, China is an interesting setting to study because China's management practices sometimes received low rating (Bloom and Van Reenen, 2010) while it is unquestionable that Chinese firms have achieved great success in the past few decades. Also contrary to Bloom and Van Reenen (2010), Hout and Michael (2014) point out that Chinese manufacturing firms have developed unique business management practices and have provided many management lessons during the last few decades through learning to cope with the rapidly changing and turbulent environment; they are much more nimble than most Western corporations.

This research uses manufacturing firms in China to study inventory production, decision-making, and management control. Further, this research examines whether inventory production is associated with firm performance. The inventory production practices in Chinese manufacturing firms can offer more insight into the role of decision-making and management control.

\subsection{Management Accounting Practices in China}

China is an important economic power and the world's largest manufacturer. Since China started economic reform and opened the markets to the world in 1978, manufacturing firms are fast growing in China. "Made in China" has dominated the consumer markets worldwide. Management practices as well as management accounting practices are pivotal to firms' success. Although many Chinese firms become privatized and compete in the global markets, they still face many challenges and risks in the management accounting practices in China (Schiff 2013) that are different from the U.S. or other developed Western economies. China is generally considered a developing country with poor management practices. In a study examining management practices across countries, Bloom and Van Reenen (2010) surveyed 524 Chinese firms, and based on answers to 18 questions, China scored 2.72 in monitoring management, 
2.53 in targets management, and 2.66 in incentives management. China's overall management score, was 2.64, based on the average of the above three categories - the lowest of seventeen countries in Bloom and Van Reenen (2010). Among the three management functions - monitoring, targets, and incentives, monitoring scored the highest in China, which to some extent coincides with the management accounting research findings in China.

The fit of management practices in a country is often attributed to the culture in a country. Contingency theory (Otley $1980,2016)$ posits that effective accounting methods and practices vary across firms and countries. The modern management accounting practices are mostly originated in developed Western countries with cultures distinctly different from China. The modern core values in China are strongly influenced by Confucianism. The ancient Chinese philosopher, Confucius, believed in societal order and harmony. Different from Western cultures that are centered on individualism, Chinese culture prefers collectivism that everyone behaves according to the prescribed role in the hierarchy. Most private Chinese firms have a Confucian preference for simple organizational structure, with everyone reporting to the top (Hout and Michael 2014). The national culture further affects corporate culture, and then managers' behaviors. Chow et al. (2000) show that compared to the U.S., Chinese managers have a higher propensity to share information that can damage their own interest but benefit the firms and less inclined to share information with other employees who are not considered to be the inner circle.

Further, the management accounting practices and techniques are developed in firms in Western countries with market based economy. China, however, is still mostly, centralized economy, or a hybrid at the best and often described as "capitalism with Chinese characteristics". The modern management accounting practices may not always be a good fit for Chinese firms also because of this institutional difference. Thus adopting all modern management accounting practices in the same manner as in Western countries without considering the cultural, social and economical differences in China probably would not be successful.

Currently, Chinese firms still lag behind in using the modern management accounting practices and techniques adopted in more developed countries (Chow et al. 2007). The management accounting practices adopted by Chinese firms in recent years seem to be focused on internal control processes for increasing efficiency and effectiveness (Chow et al. 2007). Duh et al. (2009) study the usage of management accounting and controls in Chinese firms, and find that managers respond to the degree of using twelve management accounting and controls techniques ranging from "not at all" to "very extensively". Among the twelve management accounting techniques surveyed, operating budgets, cost-volume-profit analysis, responsibility accounting, and performance-based compensation received highest responses (Duh et al. 2009). The Duh et al. (2009) study suggests that Chinese firms have different degrees in adoption of the modern management accounting practices, and also certain management accounting techniques are more widely used than others.

The most widely adopted Western management accounting practices by Chinese firms are strategic planning and budgeting systems (Chow et al. 2007). Duh et al. (2009) show that operating budgets receive the highest score from surveying managers' use of management accounting techniques. However, the use of formal planning and budget controls by Chinese firms is still in its infancy (O'Connor et al. 2011). For example, Handfield and McCormack (2005) study the supply chain maturity of Chinese suppliers and find that less than $10 \%$ of the suppliers in a sample of 55 firms reported using formal master budgets based on sales forecasts and operations planning. Another research shows that the subordinator's budgeted numbers were asked to revise by the headquarters to an impossible number in a Chinese firm (Yang and Modell 2015, 16).

Whereas some differences documented in some studies, Hopper et al. (2009) does not find the differences in management accounting techniques used in developed countries and developing countries, however, points out that the difference lies in the interplay of management accounting system and the cultural, political, and economical differences across countries. The management accounting's control function is likely to play a more important role in Chinese firms because of the following two related reasons originating from Chinese characteristics capitalism and its impact on management accounting practices.

First, Chinese companies are strongly influenced by the government. Chinese government has high stakes in the private companies. Yang and Modell (2015) conduct a longitudinal field study on management accounting practices in a Chinese state-owned enterprise privatised into a modernized cooperation, which is listed on the stock markets with majority shares owned by the central government. During the process of the market oriented reform for this Chinese firm, Yang and Modell (2015) find that the shareholder oriented management control challenged the extant central planning influence control practices and ultimately acquiesce to the extant control practices, often a result of compliance with political authorities without contestation.

Second, Chinese firms management accounting practices are greatly influenced by foreign direct investments and are 
more likely to adopt Western management accounting practices if they rely more on foreign capitals (O'Connor et al. 2004; O'Conner et al. 2011). O'Connor et al. (2004) find a significant association between the adoption of Western management accounting practices by China's state-owned enterprises and the firms' joint venture experience and stock market listing. Some industries are restrictive in terms of complete privatizations. For example, automotive industry is not allowed to be wholly foreign owned and the only way for foreign capitals enter this industry is through international joint-ventures ( $\mathrm{Li}$ et al. 2013). Chinese government and the foreign partner can use management controls as means to protect their input resources and ensure the achievement of the strategic objectives while both collaborative and competitive forces are simultaneously at work with the international joint-ventures ( $\mathrm{Li}$ et al. 2013). Since private investors may have bias towards the government central control and trust issue, a tighter management control may be needed.

Thus, we propose our first research question as follows. If Chinese manufacturing firms prefer control centered management accounting practices, we expect to find the association between inventory production and the past period sales. If management accounting practices in Chinese manufacturing firms are decision-making oriented, we expect to find the association between inventory production and the future period sales.

Research Question 1: Is inventory production in Chinese manufacturing firms associated with past sales information or future sales information?

Although China is one of the developing countries with a low score in management practice (Bloom and Van Reenen, 2010), the number and size of firms grows at a rapid rate, which makes China the fastest growing economy. Using return on invested capital and controlling for the balance sheet conservatism, Chinese firms are found to be more profitable than their U.S. counterparts (Liu et al. 2015). When the growth rate is controlled, U.S. firms are found to be more efficient in generating more free cash flows than Chinese firms (Liu et al. 2015). Since greater firm values cannot be created without efficient and effective good management practice, we look into Chinese firms production costs specifically to gauge how these firms manage their inventory production and how they are associated with the profitability. The aforementioned three management scores (Bloom and Van Reenen, 2010) in China corroborate the management emphasis, i.e., among the three management types - monitoring, targets, and incentives, monitoring is scored the highest.

Based on the preceding discussion, we next examine whether the profitability in these firms is associated with the choice of using past or future information in production.

Research Question 2: Is the different use of information to determine inventory production related to Chinese manufacturing firms' profitability?

\section{Sample and Results}

We obtain from Computstat Global all Chinese manufacturing firms with four digit SIC code 2000-3999 in the period 2005-2013. To be included in the sample, firms must have data available to estimate the production cost models used to test research questions. Finally, we delete extreme observations with variables in the top and bottom one percent. This sample selection procedure results in 7,631 firm-year observations. The descriptive statistics of key variables are summarized in Table 1. AT is total assets, SALE is sales revenue, COGS is cost of goods sold, INVT is total inventory, and all of them are measured in millions. On average, inventories account for about seventeen percent of the total assets $(918.39 / 5,361.00)$, and cost of goods sold account for about sixty three percent of the total sales revenue $(3,404.38 / 4285.65)$.

Table 1. Descriptive Statistics of Total Assets, Sales, Cost of Goods Sold, and Inventory

\begin{tabular}{lcccc}
\hline & Mean & Std. Dev. & Median. & N \\
\hline AT & $5,361.00$ & $14,969.54$ & $1,765.48$ & 7,631 \\
SALE & $4,285.65$ & $14,603.38$ & $1,121.12$ & 7,631 \\
COGS & $3,404.38$ & $12,249.20$ & 786.80 & 7,631 \\
INVT & 918.39 & $2,634.04$ & 241.93 & 7,631
\end{tabular}

The final sample consists of 7,631 firm-year observations with SIC code 2000-3999 during the period 2005-2013.

AT is total assets, SALE is sales revenue, COGS is cost of goods sold, INVT is total inventory, and all variables are in 
millions.

We first estimate a model in which the production costs are a function of current period sales, current period sales change, and future period sales change. This model is generally consistent with the budgeting for production that considers current demand and demand changes. The model is expressed below in equation (1). In this model, the dependent variable, $\mathrm{PROD}_{\mathrm{t} / \mathrm{TA}} \mathrm{t-1}$, is the sum of the cost of goods sold and the change in inventory during the year scaled by total assets at the beginning of the year. The independent variables are inverse of total assets, sales scaled by total assets, change in sales in the current period, and change in sales in the future period. SALES $\mathrm{TA}_{\mathrm{t}-1}$ is total sales scaled by total assets at the beginning of the year, $\triangle \mathrm{SALES}_{\mathrm{t}} / \mathrm{TA}_{\mathrm{t}-1}$ is current year sales change scaled by total assets at the beginning of the year, $\triangle \mathrm{SALES}_{\mathrm{t}+1} / \mathrm{TA}_{\mathrm{t}-1}$ is future year sales change scaled by total assets at the beginning of the year.

$$
\text { PROD }_{\mathrm{t} /} \mathrm{TA}_{\mathrm{t}-1}=\alpha 0+\alpha 1\left(1 / \mathrm{TA}_{\mathrm{t}-1}\right)+\alpha 2\left(\mathrm{SALES}_{\mathrm{t}} / \mathrm{TA}_{\mathrm{t}-1}\right)+\alpha 3\left(\Delta \mathrm{SALES}_{\mathrm{t}} / \mathrm{TA}_{\mathrm{t}-1}\right)+\alpha 4\left(\Delta \mathrm{SALES}_{\mathrm{t}+1} / \mathrm{TA}_{\mathrm{t}-1}\right)+\varepsilon_{\mathrm{t}}
$$

To cope with the impact of influential observations on the statistical inference, we use robust regression based on MM estimation (Leone et al., 2015) to estimate our models. Table 2 reports the robust regression results of equation (1). The first column presents the results for the model including only the current period sales growth independent variable, and the second column results are based on the model with two sales growth variables as in equation (1). In both columns, the current period sales variable is statistically positive, and the current period sales growth variable is statistically negative. In the second column, the future period sales growth variable is not statistically significant $(\alpha 4=0.0090, t=1.40)$. The results suggest that the production is not associated with the future period sales changes in these Chinese manufacturing firms.

Table 2. Regression Results of Production Costs Model Based on Future Period Sales Changes

\begin{tabular}{lll}
\multicolumn{1}{c}{ PROD $_{\mathrm{t} / \mathrm{TA}_{\mathrm{t}-1}=\alpha 0+\alpha 1\left(1 / \mathrm{TA}_{\mathrm{t}-1}\right)+\alpha 2\left(\mathrm{SALES}_{\mathrm{t}} / \mathrm{TA}_{\mathrm{t}-1}\right)+\alpha 3\left(\Delta \mathrm{SALES}_{\mathrm{t}} / \mathrm{TA}_{\mathrm{t}-1}\right)+\alpha 4\left(\Delta \mathrm{SALES}_{\mathrm{t}+1} / \mathrm{TA}_{\mathrm{t}-1}\right)+\varepsilon_{\mathrm{t}}(1)}$} & $\mathrm{Dep}=\mathrm{PROD}_{\mathrm{t} / \mathrm{TA}_{\mathrm{t}-1}}=\mathrm{PROD}_{\mathrm{t}} \mathrm{TA}_{\mathrm{t}-1}$ & $-0.0674 * * *$ \\
\hline Intercept & $-0.0675^{* * *}$ & $(16.74)$ \\
& $(16.75)$ & $-23.1898^{* * *}$ \\
$1 / \mathrm{TA}_{\mathrm{t}-1}$ & $-23.0587 * * *$ & $(24.39)$ \\
& $(24.37)$ & $0.8770^{* * *}$ \\
SALES $_{\mathrm{t}} / \mathrm{TA}_{\mathrm{t}-1}$ & $0.8781^{* * *}$ & $(188.31)$ \\
& $(191.21)$ & $-0.0414 * * *$ \\
$\Delta \mathrm{SALES}_{\mathrm{t}} / \mathrm{TA}_{\mathrm{t}-1}$ & $-0.0397 * * *$ & $(4.08)$ \\
& $(3.94)$ & 0.0090
\end{tabular}

$\begin{array}{lll}\text { Adj. } \mathrm{R}^{2} & 0.8838 & 0.8838\end{array}$

N 7,631

$* * *, * *, *$ statistically significant at the $1 \%, 5 \%, 10 \%$ levels for a two-tailed test. t-statistics are in parentheses.

$\mathrm{PROD}_{\mathrm{t} /} \mathrm{TA}_{\mathrm{t}-1}$, is the sum of the cost of goods sold and the change in inventory during the year scaled by total assets at the beginning of the year. TA is total assets. SALES $/ \mathrm{TA}_{\mathrm{t}-1}$ is total sales scaled by total assets at the beginning of the year. $\triangle$ SALES $_{t} / T_{t-1}$ is current year sales change scaled by total assets at the beginning of the year. $\triangle \mathrm{SALES}_{\mathrm{t}+1} / \mathrm{TA}_{\mathrm{t}-1}$ is future year sales change scaled by total assets at the beginning of the year.

We next estimate a model (Roychowdhury 2006) in which production costs are a function of sales, current period sales change and past period sales change as in equation (2). The dependent variable, $\mathrm{PROD}_{\mathrm{t} / \mathrm{TA}} \mathrm{t}_{-1}$, is the sum of the cost of 
goods sold and the change in inventory during the year scaled by total assets at the beginning of the year. The independent variables are inverse of total assets $\left(1 / \mathrm{TA}_{\mathrm{t}-1}\right)$, sales scaled by total assets $\left(\mathrm{SALES}_{\mathrm{t}} / \mathrm{TA}_{\mathrm{t}-1}\right)$, change in sales in the current period $\left(\triangle \mathrm{SALES}_{\mathrm{t}} / \mathrm{TA}_{\mathrm{t}-1}\right)$, and change in sales in the past period $\left(\triangle \mathrm{SALES}_{\mathrm{t}-1} / \mathrm{TA}_{\mathrm{t}-1}\right)$.

$$
\text { PROD }_{\mathrm{t} /} \mathrm{TA}_{\mathrm{t}-1}=\alpha 0+\alpha 1\left(1 / \mathrm{TA}_{\mathrm{t}-1}\right)+\alpha 2\left(\mathrm{SALES}_{\mathrm{t}} / \mathrm{TA}_{\mathrm{t}-1}\right)+\alpha 3\left(\Delta \mathrm{SALES}_{\mathrm{t}} / \mathrm{TA}_{\mathrm{t}-1}\right)+\alpha 4\left(\Delta \mathrm{SALES}_{\mathrm{t}-1} / \mathrm{TA}_{\mathrm{t}-1}\right)+\varepsilon_{\mathrm{t}}
$$

Table 3 reports the robust regression results of equation (2). The first column reports the results for the model including only the current period sales growth independent variable, and the second column results are based on equation (2). In both columns, the estimated coefficients on the current period sales and the current period sales growth variables are statically significant. In the second column, the estimated coefficient on the past sales grow variable is statistically negative $(\alpha 4=-0.1239, \mathrm{t}=10.89)$. The results suggest that the production is associated with the past period sales changes in our sample.

Table 3. Regression Results of Production Costs Model Based on Past Period Sales Changes

\begin{tabular}{|c|c|c|}
\hline & Dep $=\operatorname{PROD}_{t /} \mathrm{TA}_{\mathrm{t}-1}$ & Dep $=\mathrm{PROD}_{\mathrm{t} /} \mathrm{TA}_{\mathrm{t}-1}$ \\
\hline \multirow[t]{2}{*}{ Intercept } & $-0.0675 * * *$ & $-0.0716 * * *$ \\
\hline & $(16.75)$ & $(17.83)$ \\
\hline \multirow[t]{2}{*}{$1 / \mathrm{TA}_{\mathrm{t}-1}$} & $-23.0587 * * *$ & $-22.5167 * * *$ \\
\hline & $(24.37)$ & $(23.93)$ \\
\hline \multirow[t]{2}{*}{ SALES $_{\mathrm{t}} / \mathrm{TA}_{\mathrm{t}-1}$} & $0.8781 * * *$ & $0.8996 * * *$ \\
\hline & (191.21) & (181.11) \\
\hline \multirow[t]{2}{*}{$\Delta \mathrm{SALES}_{\mathrm{t}} / \mathrm{TA}_{\mathrm{t}-1}$} & $-0.0397 * * *$ & $-0.0522 * * *$ \\
\hline & $(3.94)$ & $(5.19)$ \\
\hline \multirow[t]{2}{*}{$\Delta$ SALES $_{\mathrm{t}-1} / \mathrm{TA}_{\mathrm{t}-1}$} & & $-0.1239 * * *$ \\
\hline & & $(10.89)$ \\
\hline Adj. $R^{2}$ & 0.8838 & 0.8856 \\
\hline $\mathrm{N}$ & 7,631 & 7,631 \\
\hline
\end{tabular}

PROD $_{t} \mathrm{TA}_{\mathrm{t}-1,1}$ is the sum of the cost of goods sold and the change in inventory during the year scaled by total assets at the beginning of the year. TA is total assets. SALES $/ \mathrm{TA}_{\mathrm{t}-1}$ is total sales scaled by total assets at the beginning of the year.

$\triangle \mathrm{SALES}_{\mathrm{t}} / \mathrm{TA}_{\mathrm{t}-1}$ is current year sales change scaled by total assets at the beginning of the year. $\triangle \mathrm{SALES}_{\mathrm{t}-1} / \mathrm{TA}_{\mathrm{t}-1}$ is prior year sales change scaled by total assets at the beginning of the year.

We also form a model where the production is a function of both past and future period sales growth variables. The equation (3), combining all variables from equation (1) and (2), is expressed as below:

$$
\text { PROD }_{\mathrm{t} /} \mathrm{TA}_{\mathrm{t}-1}=\alpha 0+\alpha 1\left(1 / \mathrm{TA}_{\mathrm{t}-1}\right)+\alpha 2\left(\mathrm{SALES}_{\mathrm{t}} / \mathrm{TA}_{\mathrm{t}-1}\right)+\alpha 3\left(\Delta \mathrm{SALES}_{\mathrm{t}} / \mathrm{TA}_{\mathrm{t}-1}\right)+\alpha 4\left(\Delta \mathrm{SALES}_{\mathrm{t}-1} / \mathrm{TA}_{\mathrm{t}-1}\right)+\alpha 5\left(\Delta \mathrm{SALES}_{\mathrm{t}+1} / \mathrm{TA}_{\mathrm{t}-1}\right)+\varepsilon_{\mathrm{t}}
$$

The robust regression results of equation (3) are summarized in Table 4. Similarly, we present the results in two columns, with one column including only the current period sales growth variable and the other column for the full model. Consistent with earlier results, the estimated coefficient on the current period sales is significantly positive and the estimated coefficient on the current period sales grow variable is statistically negative in both columns. In the second column, the estimated coefficient on the past sales growth variable is statistically negative $(\alpha 4=-0.1234$, $\mathrm{t}=10.82)$, and the estimated coefficient on the future sales growth variable is insignificant $(\alpha 5=0.0044, \mathrm{t}=0.69)$. 
Table 4. Regression Results of Production Costs Model Based on Past and Future Period Sales Changes

\begin{tabular}{|c|c|c|}
\hline & Dep $=$ PROD $_{t} T A_{t-1}$ & Dep $=$ PROD $_{t} T A_{t-1}$ \\
\hline \multirow[t]{2}{*}{ Intercept } & $-0.0675^{* * *}$ & $-0.0716^{* * *}$ \\
\hline & $(16.75)$ & $(17.82)$ \\
\hline \multirow[t]{2}{*}{$1 / \mathrm{TA}_{\mathrm{t}-1}$} & $-23.0587 * * *$ & $-22.5734 * * *$ \\
\hline & $(24.37)$ & $(23.88)$ \\
\hline \multirow[t]{2}{*}{ SALES $_{t} / \mathrm{TA}_{\mathrm{t}-1}$} & $0.8781 * * *$ & $0.8989 * * *$ \\
\hline & (191.21) & $(178.05)$ \\
\hline \multirow[t]{2}{*}{$\Delta$ SALES $_{\mathrm{t}} / \mathrm{TA}_{\mathrm{t}-1}$} & $-0.0397 * * *$ & $-0.0531 * * *$ \\
\hline & (3.94) & $(5.24)$ \\
\hline \multirow[t]{2}{*}{$\Delta \mathrm{SALES}_{\mathrm{t}-1} / \mathrm{TA}_{\mathrm{t}-1}$} & & $-0.1234 * * *$ \\
\hline & & $(10.82)$ \\
\hline \multirow[t]{2}{*}{$\Delta \mathrm{SALES}_{\mathrm{t}+1} / \mathrm{TA}_{\mathrm{t}-1}$} & & 0.0044 \\
\hline & & $(0.69)$ \\
\hline Adj. $R^{2}$ & 0.8838 & 0.8856 \\
\hline $\mathrm{N}$ & 7,631 & 7,631 \\
\hline
\end{tabular}

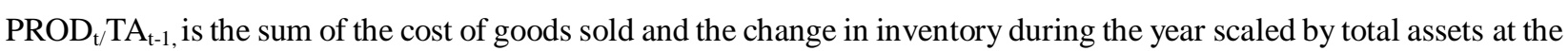
beginning of the year. TA is total assets. SALES $/ / \mathrm{TA}_{\mathrm{t}-1}$ is total sales scaled by total assets at the beginning of the year.

$\triangle \mathrm{SALES}_{\mathrm{t}} / \mathrm{TA}_{\mathrm{t}-1}$ is current year sales change scaled by total assets at the beginning of the year. $\triangle \mathrm{SALES}_{\mathrm{t}-1} / \mathrm{TA}_{\mathrm{t}-1}$ is prior year sales change scaled by total assets at the beginning of the year. $\triangle \mathrm{SALES} \mathrm{S}_{\mathrm{t}+1} / \mathrm{TA}_{\mathrm{t}-1}$ is future year sales change scaled by total assets at the beginning of the year.

Overall, our results in Tables 2, 3 and 4 suggest that Chinese manufacturing firms rely more on the past information in the production decisions. The association between inventory production and past period sales changes indicate that firms have had misaligned sales and production in the past period, thus the current period production respond to correct it.

We further analyze the use of past or future information by industry. We estimate equation (3) for each two-digit sic code, and results are summarized in Table 5. In most industrial sectors, 9 out of 13 in our sub-samples, the production costs are significantly associated with the past period sales changes. The results suggest that this practice is common in many manufacturing industries. 
Table 5. Summary of Regression Results of Equation (3) by Two-Digit SIC code

\begin{tabular}{|c|c|c|c|c|c|c|}
\hline & & $\alpha 3$ & $\alpha 4$ & $\alpha 5$ & Adj. $R^{2}$ & $\mathrm{~N}$ \\
\hline 20 & Food and Kindred Products & -0.0310 & $-0.1278 *$ & 0.0200 & 0.8373 & 444 \\
\hline 21 & Tobacco Products & & & & & \\
\hline 22 & Textile Mill Products & $0.169 * * *$ & -0.036 & 0.0145 & 0.9218 & 324 \\
\hline 23 & Apparel and others & -0.0438 & $-0.2497 * *$ & 0.0192 & 0.8718 & 132 \\
\hline 24 & Lumber and Wood Products & & & & & \\
\hline 25 & Furniture and Fixtures & & & & & \\
\hline 26 & Paper and Allied Products & -0.0583 & $-0.0845^{*}$ & 0.0071 & 0.9448 & 187 \\
\hline 27 & $\begin{array}{l}\text { Printing, Publishing, and Allied } \\
\text { Industries }\end{array}$ & & & & & \\
\hline 28 & Chemicals and Allied Products & $-0.1646 * * *$ & $-0.1123 * * *$ & -0.0071 & 0.8375 & 1,823 \\
\hline 29 & $\begin{array}{l}\text { Petroleum Refining and Related } \\
\text { Industries }\end{array}$ & & & & & \\
\hline 30 & $\begin{array}{l}\text { Rubber and Miscellaneous Plastics } \\
\text { Products }\end{array}$ & 0.0452 & $-0.0924^{*}$ & -0.0517 & 0.9300 & 233 \\
\hline 31 & Leather and Leather Products & & & & & \\
\hline 32 & $\begin{array}{l}\text { Stone, Clay, Glass and Concrete } \\
\text { Products }\end{array}$ & $-0.0729 *$ & $-0.2599 * * *$ & 0.0075 & 0.8306 & 343 \\
\hline 33 & Primary Metal Industries & -0.2453 & $-0.1030 * * *$ & $0.0831 * * *$ & 0.9460 & 631 \\
\hline 34 & Fabricated Metal Products & $0.0645^{*}$ & -0.0388 & $0.049^{* *}$ & 0.9402 & 254 \\
\hline 35 & $\begin{array}{l}\text { Industrial and Commercial } \\
\text { Machinery and Computer } \\
\text { Equipment }\end{array}$ & $-0.0391 *$ & $-0.1003 * * *$ & -0.0032 & 0.9301 & 1,023 \\
\hline 36 & $\begin{array}{l}\text { Electronic and other Electrical } \\
\text { Equipment and Components, } \\
\text { except Computer Equipment }\end{array}$ & 0.1524 & $-0.1081 * * *$ & $-0.0212 *$ & 0.9116 & 1,316 \\
\hline 37 & Transportation Equipment & 0.0255 & $-0.0544 *$ & 0.0085 & 0.9264 & 529 \\
\hline 38 & $\begin{array}{l}\text { Measuring, Analyzing, and } \\
\text { Controlling Instruments; } \\
\text { Photographic, Medical and Optical } \\
\text { Goods; Watches and Clocks }\end{array}$ & -0.0143 & -0.0747 & $0.1211 * * *$ & 0.8920 & 266 \\
\hline 39 & $\begin{array}{l}\text { Miscellaneous Manufacturing } \\
\text { Industries }\end{array}$ & 0.1275 & -0.0891 & $0.1683^{* *}$ & 0.9069 & 126 \\
\hline
\end{tabular}

$* * *, * * *$ statistically significant at the $1 \%, 5 \%, 10 \%$ levels for a two-tailed test. t-statistics are in parentheses.

$\mathrm{PROD}_{\mathrm{t} /} \mathrm{TA}_{\mathrm{t}-1,1}$ is the sum of the cost of goods sold and the change in inventory during the year scaled by total assets at the beginning of the year. TA is total assets. SALES $/ \mathrm{TA}_{\mathrm{t}-1}$ is total sales scaled by total assets at the beginning of the year.

$\triangle \mathrm{SALES}_{\mathrm{t}} / \mathrm{TA}_{\mathrm{t}-1}$ is current year sales change scaled by total assets at the beginning of the year. $\triangle \mathrm{SALES}_{\mathrm{t}-1} / \mathrm{TA}_{\mathrm{t}-1}$ is prior year sales change scaled by total assets at the beginning of the year. $\triangle \mathrm{SALES}_{\mathrm{t}+1} / \mathrm{TA}_{\mathrm{t}-1}$ is future year sales change scaled by total assets at the beginning of the year.

Finally, we partition our sample based on return on assets (ROA). ROA is calculated as income before extraordinary items divided by total assets. We examine whether firms with different earnings use different inventory management. Two sub-samples are classified as high ROA firms and low ROA firms based on the median ROA. The robust regression results of equation (3) are presented in Table 6. The results are distinctively different between the two sub-samples. In the low ROA firms sub-sample, the estimated coefficient on current period sales change is 
significant $(\alpha 3=0.0263, t=2.68)$, the estimated coefficient on the past period sales sale is insignificant $(\alpha 4=-0.0027$, $\mathrm{t}=0.24$ ) and the estimated coefficient on future period sales change is significant $(\alpha 5=0.0526, \mathrm{t}=8.42)$. In the high ROA firms regression, the estimated coefficient on the current period sales change is insignificant $(\alpha 3=-0.0061$, $\mathrm{t}=0.38$ ), the estimated coefficient on the past period sales change is significant $(\alpha 4=-0.1218, \mathrm{t}=6.83)$, and the estimated coefficient on the future period sales change is insignificant $(\alpha 5=-0.0103, \mathrm{t}=1.05)$. When ROA is alternatively calculated based on operating income after depreciation, the results are qualitatively the same and not tabulated.

Table 6. Summary of Regression Results of Equation (3) by Return on Assets

\begin{tabular}{|c|c|c|}
\hline & Low ROA & High ROA \\
\hline \multirow[t]{2}{*}{ Intercept } & $-0.0722 * * *$ & $-0.1300 * * *$ \\
\hline & (19.07) & (19.86) \\
\hline \multirow[t]{2}{*}{$1 / \mathrm{TA}_{\mathrm{t}-1}$} & $-4.0384 * * *$ & $-21.9545 * * *$ \\
\hline & $(3.53)$ & $(16.82)$ \\
\hline \multirow[t]{2}{*}{ SALES $_{\mathrm{t}} / \mathrm{TA}_{\mathrm{t}-1}$} & $0.9256^{* * *}$ & $0.8939 * * *$ \\
\hline & (194.51) & (112.90) \\
\hline \multirow{2}{*}{$\Delta$ SALES $_{\mathrm{t}} / \mathrm{TA}_{\mathrm{t}-1}$} & $0.0263 * * *$ & -0.0061 \\
\hline & $(2.68)$ & $(0.38)$ \\
\hline \multirow{2}{*}{$\Delta$ SALES $_{\mathrm{t}-1} / \mathrm{TA}_{\mathrm{t}-1}$} & -0.0027 & $-0.1218 * * *$ \\
\hline & $(0.24)$ & $(6.83)$ \\
\hline \multirow[t]{2}{*}{$\Delta \mathrm{SALES}_{\mathrm{t}+1} / \mathrm{TA}_{\mathrm{t}-1}$} & $0.0526 * * *$ & -0.0103 \\
\hline & $(8.42)$ & $(1.05)$ \\
\hline Adj. $R^{2}$ & 0.9442 & 0.8753 \\
\hline $\mathrm{N}$ & 3,743 & 3,742 \\
\hline
\end{tabular}

ROA is income before extraordinary items divided by total assets. $\mathrm{PROD}_{\mathrm{t}} \mathrm{TA}_{\mathrm{t}-1, \mathrm{i}}$ is the sum of the cost of goods sold and the change in inventory during the year scaled by total assets at the beginning of the year. TA is total assets. SALES $/ T_{\mathrm{TA}}$ is total sales scaled by total assets at the beginning of the year. $\triangle \mathrm{SALES}_{\mathrm{t}} / \mathrm{TA}_{\mathrm{t}-1}$ is current year sales change scaled by total assets at the beginning of the year. $\triangle \mathrm{SALES}_{\mathrm{t}-1} / \mathrm{TA}_{\mathrm{t}-1}$ is prior year sales change scaled by total assets at the beginning of the year. $\triangle \mathrm{SALES}_{\mathrm{t}+1} / \mathrm{TA}_{\mathrm{t}-1}$ is future year sales change scaled by total assets at the beginning of the year.

The estimated coefficient of the current period sales change variable is statistically negative in most of the tabulated results except that in Table 6, the estimated coefficient on the current period sales change is positive for the low ROA firms and not significant for the high ROA firms. However, a positive relationship between production and the current period sales change was shown in Roychowdhury (2006). To cope with the impact of influential observations on the statistical inference, we use robust regression based on MM estimation (Leone et al. 2015) to estimate our models. The results are qualitatively the same. Although, we are unable to summarize a conclusive relationship between production costs and the current period sales change. However, we conjecture the contra-intuitive results in some tables and inconsistent results across tables are also evidence that the production is not well aligned with the sales information under normal circumstances of decision-making, a compromise for management control. It is worth noting that we did not project the direction of the relationship between the production and the sales change. 
Instead, we merely examine whether the production is associated with the sales information in different time periods.

\section{Conclusion}

Our empirical results suggest that inventory management or production scheduling in Chinese manufacturing firms are not based on forward-looking information. Instead, the past sales information play a more important role in Chinese manufacturing firms' inventory production. We also find that in firms with high ROA, current period production costs are significantly related to the past period sales changes but not related to the future period sales changes; while in firms with low ROA, current period production costs are significantly related to the future period sales changes but not related to the past period sales changes.

Different from many prior management accounting research that employs survey or filed study, this study is based on archival data with relatively large sample size. However, the use of archival data in empirical research has the limitation of the indirect inference of what managerial accounting information is employed in business practices. To directly understand how Chinese manufacturing firms schedule productions, future study can extend to a field or case study on the management practices such as budgeting, production scheduling, inventory management in Chinese manufacturing firms.

Our results do not provide further explanations on whether such pattern of inventory management is associated with the Chinese manufacturing firms' rapid growth, and the advantage or disadvantage of such inventory management pattern in the Chinese setting. Prior research in the U.S. setting found mixed results in the association between inventory management and financial performance. For example, Rumyantsev and Netessine (2007) found that inventory responsiveness to sales is associated with lower profitability. Further research can expand on this issue as well.

\section{References}

Baiman, S., S. Netessine, \& R. Saouma. (2010). Informativeness, incentive compensation, and the choice of inventory buffer. The Accounting Review, 85(6), 1839-1860. https://doi.org/10.2308/accr.2010.85.6.1839

Bloom, N., \& J. Van Reenen. (2010). Why do management practices differ across firms and countries? Journal of Economic Perspectives, 24(1), 203-224. https://doi.org/10.1257/jep.24.1.203

Bruggen, A., R. Krishnan, \& K. L. Sedatole. (2011). Drivers and consequences of short-term production decisions: evidence from the auto industry. Contemporary Accounting Research, 28(1), 83-123. https://doi.org/10.1111/j.1911-3846.2010.01042.x

Chen, C. X., K. M., Rennekamp, \& F. H. Zhou. (2015). The effects of forecast type and performance-based incentives on the quality of management forecasts. Accounting, Organizations and Society, 46(October), 8-18. https://doi.org/10.1016/j.aos.2015.03.002

Chow, C. W., R. Duh, \& Z. Xiao. (2007). Management accounting practices in the People's Republic of China. Handbook of Management Accounting Research, 2, 923-967.

Chow, C. W., F. J. Deng, \& J. L. Ho. (2000). The openness of knowledge sharing within organizations: a comparative study of the United States and the People's Republic of China. Journal of Management Accounting Research, 12(1), 65-95. https://doi.org/10.2308/jmar.2000.12.1.65

Cook, K.A., G. R. Huston, \& M. R. Kinney. (2012). Managing earnings by manipulating inventory: The effects of cost structure and valuation method. Working Paper. http://papers.ssrn.com/sol3/papers.cfm?abstract_id=997437

Dua, R., J. Z. Xiao, \& C. W. Chow. (2008). An overview and assessment of contemporary management accounting research in China. Journal of Management Accounting Research, 20(Special), 129-164.

Duh, R., J. Z. Xiao, \& C. W. Chow. (2009). Chinese firms' use of management accounting and controls: facilitators, impediments, and performance effects. Journal of International Accounting Research, 8(1), 1-30. https://doi.org/10.2308/jiar.2009.8.1.1

Handfield, R.B. \& K. McCormack. (2005). What you need to know about sourcing in China. Supply Chain Management Review, 9(5), 56-62.

Harrison, G. L. \& J. L. McKinnon. (1999). Cross-cultural research in management control systems design: a review of the current state. Accounting, Organizations and Society, 24, 483-506. https://doi.org/10.1016/S0361-3682(97)00048-2 
Hopper, T., M. Tsamenyi, S. Uddin, \& D. Wickramasinghe. (2009). Management accounting in less developed countries: what is known and need knowing. Accounting, Auditing \& Accountability Journal, 22(3), 469-514. https://doi.org/10.1108/09513570910945697

Hout, T., \& D. Michael. (2014). A Chinese approach to management. Harvard Business Review, 92(9), 103-107.

Leone, A. J., M. Minutti-Meza, \& C. E. Wasley. (2015). Influential observations and inference in accounting research. Working Paper. http://papers.ssrn.com/sol3/papers.cfm?abstract_id=2407967

Li, P., G. Tang, H. Okano, \& C. Gao. (2013). The characteristics and dynamics of management controls in IJVs: Evidence from a Sino-Japanese case. Management Accounting Research, 24(3), 246-260. https://doi.org/10.1016/j.mar.2013.04.002

Liu, J., J. Ohlson, \& W. Zhang. (2015). An evaluation of Chinese firms' profitability: 2005-2013. Accounting Horizons, 29(4), 799-828. https://doi.org/10.2308/acch-51154

O'Connor, N. G., C. W. Chow, \& A. Wu. (2004). The adoption of "Western" management accounting/controls in China's state-owned enterprises during economic transition. Accounting, Organizations and Society, 29(3-4), 349-375. https://doi.org/10.1016/S0361-3682(02)00103-4

O'Connor, N. G., S. C. Vera-Munoz, \& F. Chan. (2011). Competitive forces and the importance of management control systems in emerging-economy firms: the moderating effect of international market orientation. Accounting, Organizations and Society, 36, 246-266. https://doi.org/10.1016/j.aos.2011.04.004

Otley, D. T. (1980). The contingency theory of management accounting: achievement and prognosis. Accounting, Organizations and Society, 5(4), 413-428. https://doi.org/10.1016/0361-3682(80)90040-9

Otley, D. T. (2016). The contingency theory of management accounting and control: 1980-2014. Management Accounting Research, 31(June), 45 -62. https://doi.org/10.1016/j.mar.2016.02.001

Pong, C. \& F. Mitchell. (2012). Inventory investment \& control: how have UK companies been doing? The British Accounting Review, 44, 173-188. https://doi.org/10.1016/j.bar.2012.07.008

Roychowdhury, S. (2006). Management of earnings through the manipulation of real activities that affect cash flow from operations. Journal of Accounting and Economics, 42(3), 335-370. https://doi.org/10.1016/j.jacceco.2006.01.002

Rumyantsev, S., \& S. Netessine. (2007). Should inventory policy be lean or responsive? Working Paper. http://papers.ssrn.com/sol3/papers.cfm?abstract_id=2319834

Schiff, J. (2013). The wild, wild east: applying management accounting practices in the People's Republic of China. Management Accounting Quarterly, 14(2), 19-23.

Yang, C., \& S. Modell. (2015). Shareholder orientation and the framing of management control practices: a field study in Chinese state-owned enterprise. Accounting, Organizations and Society, 45, 1-23. https://doi.org/10.1016/j.aos.2015.06.001

Zimmerman, J. (2013). Accounting for decision making and control, $8^{\text {th }}$ edition. McGraw-Hill Education. 